\title{
The Conceptual Structure of Commercial LaW
}

\author{
TAMARA M. BUCKWOLD*
}

\begin{abstract}
This article argues that commercial law is not merely a collection of rules, but a doctrinally coherent and conceptually sophisticated body of law structured through conceptions of property. The analysis focuses specifically on the aspects of commercial law that govern recovery of debt. The argument advances two related themes; that commercial law is built around conceptions of property and reciprocally defines the conceptions of property around which it is built. The article first addresses the role of property as the structural framework of commercial law. Property creates the basis for assertion of rights and provides the conceptual interface between the legal regimes of secured financing, judgment enforcement, and bankruptcy. Further, property is the basis on which commercial law rights and interests are reconciled with rights and interests that fall outside its boundaries. The article then explores the means by which commercial law resolves practical problems through the creative definition of property. The article concludes with thoughts on the importance of understanding the central role of property in the structure and function of commercial law.
\end{abstract}

\section{TABLE OF CONTENTS}

I. INTRODUCTION . . . . . . . . . . . . . . . . . . . . . . . . . . . . 900

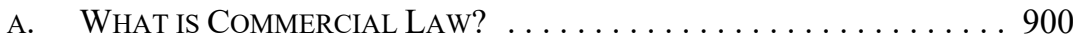

B. The Role of Property In THE CONCEPTUAL

STRUCTURE OF COMMERCIAL LAW . . . . . . . . . . . . . . . . 901

II. A SHORT PRIMER ON RECOVERY OF DeBT . . . . . . . . . . . . . . . . . . . . 904

A. Property as the Foundation for ReCOVERy . . . . . . . . . . . . . 904

B. The Property Interest of a Secured Creditor . . . . . . . . . 905

C. CONCEPTIONS OF PROPERTY IN

JUDGMENT ENFORCEMENT LAW . . . . . . . . . . . . . . . . 908

D. The PRoperty Rights of CREDitors in BANKRUPTCY . . . . . . . . 909

III. PROPERTY AS THE INTERFACE BETWEEN

DebT Recovery Regimes . . . . . . . . . . . . . . . . . . 910

IV. Property at the Boundaries of Commercial LaW . . . . . . . . . . 915

V. The Creative POWER OF COMMERCIAL LAW: Property

as the Conceptual Solution to Practical Problems . . . . . . . . 917

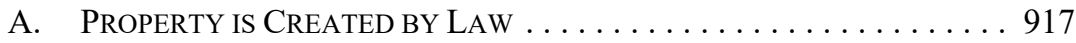

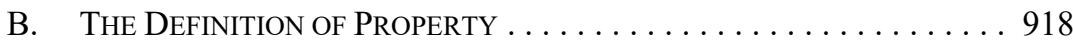

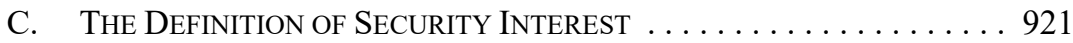

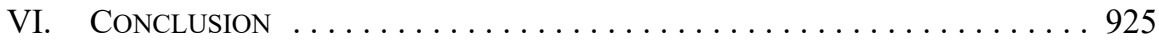

Professor, Faculty of Law, University of Alberta, Edmonton. The ideas developed in this article germinated in an invited lecture delivered at Robson Hall Faculty of Law at the University of Manitoba under the more emotive title, "Through the Eyes of a Black Letter Lawyer: How I Learned to Love Commercial Law." I wish to thank Professors Virginia Torrie and Darcy MacPherson of Robson Hall for encouraging me to turn my talk into something more. I am also grateful for the support of my colleagues at the Commercial Law Symposium 2019, graciously hosted by the University of Windsor, Faculty of Law, where I was able to deliver the paper that finally evolved into this article. 


\section{INTRODUCTION}

\section{A. What IS COMMERCiAL LaW?}

This article is about the role of property in the conceptual structure of commercial law. The analysis presupposes an understanding of the content and scope of the field designated by the term "commercial law." However, the answer to the question, "what is commercial law?" is surprisingly elusive.

The term "commercial law" is sometimes thought to refer to the law that relates to the operation of businesses and, for that reason, may be seen as synonymous with - or at least in the same family as - corporate law. That view is mistaken. Corporate law deals with the legal structure of a particular type of entity, the corporation - its constitution, ownership structure, governance, and capacities. Commercial law, in contrast, is not restricted to the structure or functioning of any particular legal entity, but addresses dealings by entities of all kinds, including humans. To the extent that generalization is possible, commercial law may be thought of as the body or bodies of law governing commercial transactions and the recovery of debt. ${ }^{1}$

The content of the leading English text, Goode on Commercial Law, ${ }^{2}$ illustrates the scope of the field. It includes sections on sale of goods, money, payment and payment systems (including negotiable instruments), secured financing (including guarantees), corporate insolvency, and international trade and finance (covering aspects of sale of goods, financing, and conflict of laws). The exposition of these substantive topics is supplemented by a survey of the basic features of the supporting law of contract and agency, and a review of commercial dispute resolution procedural law and practices. ${ }^{3}$ Other commercial law texts cover additional or different subject headings. ${ }^{4}$ Most Canadian law schools also include in their lists of commercial law course offerings topics which might include the general law of bankruptcy and insolvency (personal as well as corporate), judgment enforcement, securities transfer, and perhaps more granular topics relating to consumer level transactions or debt, such as cost of credit disclosure, payday lending, and unfair business practices.

The seemingly disparate character of the topics listed may suggest that "commercial law" is nothing more than an assemblage of rules grouped into functional categories; a collection of the collections of rules that respectively govern the various topics ascribed to the subject.

Mohamed F Khimji offers this definition of commercial law in Mohamed F Khimji, "The Role of Legal Concepts in Commercial Law: Comments on Spink, Rogers and Scavone" (2007) 45:1 Can Bus LJ 94 at 95 [Khimji, "Legal Concepts"]: "Perhaps the most accurate definition would be that it is the aggregate of both the law of things and the law of obligations relevant to the resolution of commercial disputes, whatever the form of the commercial transaction subject to the dispute." My definition is less elegant but more concrete.

2 Ewan McKendrick, ed, Goode on Commercial Law, 4th ed (London, UK: LexisNexis, 2009).

Writing elsewhere, Roy Goode defined commercial law as "that body of law which governs commercial transactions, that is, agreements and arrangements between professionals for the provision and acquisition of goods, services and facilities in the way of trade": Roy Goode, "The Codification of Commercial Law" (1988) 14:3 Monash UL Rev 135 at 141 [Goode, "Codification"]. Although Goode then suggested that bankruptcy was not commercial law as captured by this definition, the enforcement of debt through insolvency proceedings and by other means is often a feature of the transactions more generally described and aspects of debt recovery are included in Goode on Commercial Law, ibid.

4 See e.g. Fidelma White, Commercial Law (Dublin: Thomson Round Hall, 2002) at 4-9 for White's description of commercial law. 
So viewed, commercial law can be seen as practically important but conceptually and intellectually sterile; in fact, it is fair to say that it is sometimes so regarded. To those outside the discipline and perhaps even some within, commercial law is the purview of the "black letter lawyer" — one who knows the rules but need not invoke deeper principles. The object of this article is to refute that view. Commercial law has a deeply rooted and sophisticated conceptual foundation and framework. ${ }^{5}$ While mastery of the rules may be both a satisfying intellectual game and a critical practical skill, a lawyer who knows the rules of a particular subcategory of commercial law but not their conceptual grounding is likely to make errors in application and will flounder when presented with questions that require something more than a purely mechanical approach. Poorly advised legislators who venture into the territory of commercial law without understanding its conceptual basis are similarly susceptible to error. $^{6}$

\section{B. The Role of Property in the Conceptual STRUCTURE OF COMMERCIAL LAW}

What, then, grounds and unites commercial law? I am not the first and certainly not the most distinguished academic commercial lawyer to ask whether there are unifying principles underlying commercial law. The question appears as a title in the "Final Reflections" chapter of Goode on Commercial Law. ${ }^{7}$ Rather to my surprise, the answer offered in even that erudite commercial law text is less than satisfying:

\footnotetext{
This, then, is the essence of commercial law - the accommodation of rules, usages and documents fashioned by the world of business; the facilitation, rather than the obstruction, of legitimate commercial development. This is achieved not through ad hoc responses to particular problems but through the development of principles within a sound conceptual framework. Commercial law is rooted in principles of good faith, the sanctity of agreement, the recognition of trade usage as a source of contractual rights, and the maintenance of a fair balance between vested rights and the interests of third parties. ${ }^{8}$
}

For a spirited defence of the importance of concepts as opposed to mere rules in commercial law, see Goode, "Codification," supra note 3 at 145. Notably, the example offered to illustrate the difference between rules-based thinking and conceptual thinking is the debate over whether creditors can take a security interest in obligations they themselves owe to their debtors. The example illustrates the importance of property concepts in commercial law in that that an affirmative answer effectively converts an obligation owed by creditor to debtor into a species of property as between creditor and debtor which can then be the subject of a security interest taken by the creditor. The initial, and arguably correct, view of the English courts was that such an interest is conceptually impossible (see Re Charge Card Services Ltd, [1986] 3 All ER 289), but that view was reversed by the House of Lords in Re Bank of Credit and Commerce International SA (No 8), [1998] AC 214. I endorse Khimji's argument, in Khimji, "Legal Concepts," supra note 1 at 95:

[I]t is submitted that a conceptual approach to commercial law supports the objective of facilitating the legal recognition of new commercial practices. This is because, while a functional approach offers predictability by providing specific solutions to specific legal questions, a conceptual approach offers continuity by allowing for the resolution of new legal questions as new commercial practices evolve. Furthermore, even a highly functionally drafted piece of legislation, such as the STA [Securities Transfer Act, SO 2006, c 8 [STA, (Ont)]], requires at least some level of conceptual reasoning as no code can be comprehensive.

I would differ from Khimji only in that I do not regard the functional and conceptual approaches as distinct. Rather, I think that the genius of commercial law is its capacity to embody a functional approach in a conceptual notion of property. This point is elaborated below. 
The text continues with a fair description of what commercial law does, but never articulates the "sound conceptual framework" suggested. ${ }^{9}$

In fairness to the authors, the generality of the offered answer may simply reflect the proposition, advanced above, that commercial law is the body or bodies of law governing commercial transactions and the recovery of debt. It embraces both the contractual rights involved in transactional relationships and the proprietary concepts that are an aspect of many transactions and that support debt recovery. ${ }^{10}$ This amalgam of doctrines of contract and property cannot be reduced to a single conceptual structure, nor does every aspect of commercial law fit within a fully integrated set of principles. Some issues in commercial law, particularly those arising between the parties to a transaction, are essentially contractual in nature. Others depend primarily on rights of property and the intersection of competing proprietary claims.

In this article, I focus on the recovery of debt branch of commercial law and the term "commercial law" as it appears hereafter should be so understood unless the context suggests a broader meaning. While both contract and property are important in debt relationships, it is property that here provides a unifying conceptual framework and structure. ${ }^{11}$

The assertion that property provides the doctrinal core of commercial law, rather than contract, may elicit surprise if not resistance. ${ }^{12}$ This may be in part a habit of thought: law school course listings typically group commercial law with contracts rather than with property, and the work of commercial lawyers is generally seen as contract-based. Certainly, contract plays an important part, since property rights in commercial law most often arise from a contractual transaction. However, while contract may be the genesis of obligations enforced through commercial law, the concepts that comprise contract doctrine play no structural role in the body of commercial law.

First of all, contractual debt obligations are ultimately enforceable only through a proprietary claim. If $\mathrm{X}$ owes money to $\mathrm{Y}$ but fails to pay, $\mathrm{Y}$ can only recover through a conception of property rights that entitles $\mathrm{Y}$ to resort to $\mathrm{X}$ 's property for satisfaction. ${ }^{13}$

$9 \quad$ Ibid $1347-48$

10 See Khimji, "Legal Concepts," supra note 1 at 95: "[T]he legal concepts most fundamental to commercial law are property and obligation."

11 Topics in the "transactions" category might also fit within this proposition, since property is also an essential element of many subjects within the transactional category of commercial law (e.g. in sale of goods, where the locus of title is critical; in negotiable instruments, where the payment obligation is embodied in a physical item of property). See RM Goode, "Ownership and Obligation in Commercial Transactions" (1987) 103 Law Q Rev 433 [Goode, "Ownership and Obligation”], republished in Roy Goode, Fundamental Concepts of Commercial Law: Fifty Years of Reflection (Oxford: Oxford University Press, 2018), ch 6. Goode focuses his analysis of ownership and obligation in commercial law on two cases: ownership in insolvency (the debt recovery branch of commercial law) and ownership under a contract for sale of goods (the commercial transactions branch). Further, one might argue that the category of transactional law collapses into that of debt recovery, since a transaction often entails a debt (e.g. the obligation to pay under a guarantee) or produces a debt (e.g. the liability of the maker or endorser of a negotiable instrument). While I am tempted to press the argument, the point is beyond the scope of this article and will not be pursued.

12 Goode suggests that the law of contract is at the core of commercial law, but does not explain or defend the assertion and, in particular, does not compare the conceptual function of contract doctrine with that of property. See Roy Goode, Commercial Law in the Next Millennium (London, UK: Sweet \& Maxwell, 1998) at 9. A chapter in the same volume is devoted to the importance of the characterization of property rights in commercial law (ibid at 59-80). See Part II below. 
More importantly, contract creates the inter partes rights and obligations associated with a commercial transaction but does not explain the structure of transactional relationships as among themselves. A contract between $\mathrm{X}$ and $\mathrm{Y}$ may give $\mathrm{Y}$ certain rights as against $\mathrm{X}$ and X's property (for example a security interest) but contract as a concept does not provide a basis for determining Y's rights as against another person, Z, who has also contracted with $\mathrm{X}$. Property provides the framework through which competing rights are ordered both within a particular branch of commercial law and across branches. ${ }^{14}$ Property also provides a conceptual bridge between claims in commercial law and claims arising under other legal doctrines. ${ }^{15}$ Although the respective claims of $\mathrm{Y}$ and $\mathrm{Z}$ may have originated in contract, they are ordered by concepts of property.

Further, the definition of rights through concepts of property achieves results that cannot be achieved by contract alone. Y's contractual rights against $\mathrm{X}$ have no direct impact on the position of $Z$, who is not a party to the contract. In contrast, Y's rights as embodied in an interest in X's property will potentially restrict the rights $Z$ can assert against $X$, and $Z$ cannot avoid Y's rights by contracting with $\mathrm{X}$. The attributes ascribed to the property interest, once it is recognized, determine central aspects of the rights of the parties to a transaction both as between themselves and against third parties regardless of the contractual provisions under which the interest arose. ${ }^{16}$

Finally, while commercial law may involve characteristic types of contractual relationships, contract doctrine does not operate differently in commercial law than it does in the law at large. Property, by contrast, is defined and utilized by commercial law in ways specifically tailored to the law's particular function. ${ }^{17}$

The proposition that property provides the foundation for and structural framework of commercial law is the first theme of my article. The second and related theme is the conceptual creativity of commercial law. While property provides the conceptual basis of commercial law, commercial law in turn defines property; the relationship between the rules of commercial law and our conception of property is symbiotic.

My themes emerge largely from an analysis of core commercial statutes. However, they are buttressed by the handful of cases in which the Supreme Court of Canada has addressed issues arising from modern commercial legislation. Property plays a central role in every

See Part III below.

See Part IV below.

See Sarah Worthington, "Property as Proxy for Policy in Commercial Law Adjudication" (2006) 25:2 UQLJ 329 [Worthington, "Property as Proxy"] for essentially the same point advanced in relation to the trust, which accommodates a division of property interest described by the author as "asset partitioning" (ibid at 339). After outlining the development of the property interests created by the law of trusts and describing the utility and significance of those interests in commercial law, Worthington posits that, "[a]sset partitioning cannot be explained simply by contract" (ibid [footnotes omitted]). 
recent Supreme Court decision addressing the areas of commercial law considered in this article. $^{18}$

I preface the analysis that follows with an overview of the role of property in the law governing debt recovery (Part II). I then consider the structural role of property in commercial law; internally, in connecting the branches of law governing debt recovery (Part III) and externally, by connecting rights governed by commercial law with rights arising under other areas of legal doctrine (Part IV). The discussion then shifts to my second theme; the manner in which commercial law legislation and judicial decisions use concepts of property to achieve commercial ends (Part V). I end with concluding thoughts on the importance of understanding the central role of property in the structure and function of commercial law.

\section{A Short Primer on Recovery OF DEbT}

\section{A. Property as The Foundation for ReCOVERY}

In Anglo-Canadian law, debt that is not voluntarily paid can be recovered in only one way: by the appropriation of property of the debtor to satisfaction of the debt in the manner permitted by law. The law of personal property security (secured transactions) allows a creditor who takes a security interest in property of the debtor to seize and sell the subject property (the collateral) to generate funds that may be applied to satisfaction of the debt or, in the case of property in the form of an account, to collect the account and apply the proceeds to the debt. ${ }^{19}$ The holder of an unsecured debt, including a judgment debt, has no rights in or in relation to the debtor's property. ${ }^{20}$ The debt can only be recovered under provincial judgment enforcement law or through the federal law of bankruptcy; systems that

18 My discussion is restricted to the operation of commercial law in relation to personal property. This approach is justified both by the need for manageable limits of scope and length and by the fact that the subject of commercial law is generally associated with personal property rather than land. See Goode on Commercial Law, supra note 2 at 27 [footnotes omitted]: "While the financing of business operations frequently involves the grant of security over land, about which we shall have something to say later, commercial law is primarily concerned with dealings in personal property, tangible and intangible." See e.g. Personal Property Security Act, RSA 2000, c P-7, Part 5 [PPSA (Alta)]; Ronald CC Cuming, Catherine Walsh \& Roderick J Wood, Personal Property Security Law, 2nd ed (Toronto: Irwin Law, 2012), ch 12.

20 Regarding the position of the unsecured creditor generally, see Goode on Commercial Law, supra note 2 at 624-25 [footnotes omitted]:

Until the debtor's bankruptcy or winding up, the unsecured creditor lacks even a vestigial interest

in the debtor's property. He has no claim either to a specific asset or to a fund, merely the right to sue for his money and to invoke the processes of the law to enforce a judgment against the defendant.

Regarding the effect of judgment, see CRB Dunlop, Creditor-Debtor Law in Canada, 2nd ed (Toronto: Carswell, 1995) at 205-10. Dunlop summarizes the effect of judgment at common law and in equity with the assertion that "the obtaining of a money judgment against a debtor does not create any lien or other interest in the debtor's property" (ibid at 206). That proposition is qualified in the United States by recognition of a judgment lien against land arising from judgment alone. However, Dunlop concludes that, with the possible exception of New Brunswick and perhaps Newfoundland, Canadian common law jurisdictions do not recognize a judgment lien. The suggestion that New Brunswick law may recognize a lien against land based on judgment alone is contradicted by the more recent decision in Cooper \& Lewis v Gorber, 2000 NBCA 7. The Court of Appeal of New Brunswick held that a judgment creditor could claim an interest in the debtor's land only if and for so long as a memorial of judgment was registered under the Memorials and Executions Act, RSNB 1973, c M-9, now replaced by the Enforcement of Money Judgment Act, SNB 2013, c 23 [EMJA (NB)]. The former provides that registration of a memorial of judgment "binds" the lands of a judgment debtor (Memorials and Executions Act, ibid, ss 5-6). The concept appears in modified form in the latter, under which registration of a judgment (rather than a memorial) binds the debtor's land (EMJA (NB), ibid, s 30). 
respectively offer different pathways to recovery through different conceptions of property rights.

The scope of a creditor's recovery is determined by two factors: first, by the manner in which the property rights supporting the enforcement of secured and unsecured debt, respectively, is conceived; and second, by the rules of law overlaid on those rights to rank their priority in the event of competing claims. While priority rules are essential, their proper application depends on the first factor; namely, the nature and extent of the rights of property to which they are applied. In some contexts, the nature and extent of the property rights involved may implicitly dictate the priority of competing claims.

\section{B. The Property Interest of A Secured Creditor}

Before enactment of the provincial and territorial Personal Property Security Acts $(P P S A)^{21}$ that now govern secured transactions in all Canadian common law jurisdictions, the rights of secured creditors were largely determined by their title to the property that served as collateral. A lender who took a chattel mortgage was entitled to seize and sell the collateral if the debtor defaulted in payment because the collateral was in law property of the lender. Similarly, the seller of goods under a conditional sale agreement was entitled to take the collateral if the buyer defaulted in paying the price because the seller held title to the goods. The characterization of the creditor's property interest in terms of title had implicit priority consequences. In principle, other creditors of the debtor-chattel mortgagor or conditional buyer, including those claiming through judgment enforcement or bankruptcy, could not take property owned by someone other than the debtor: nemo dat quod non habet (nemo dat). However that outcome was modified by the imposition of statutory requirements that precluded the creditor-owner of the property in question from asserting their interest if it was not registered in the manner prescribed. ${ }^{22}$

This title-based conception of the rights of secured creditors was adopted in the federal Bank Act of the early 20th century and persists in its current iteration. ${ }^{23}$ Bank Act security is available only to banks falling within the Act, not to provincially regulated financial institutions such as credit unions. ${ }^{24}$ The following explanation of section 427 of the Bank Act,

$21 \quad$ All provincial and territorial PPSAs share the same conceptual structure and central rules. Although the Supreme Court of Canada decisions discussed in this article are addressed, respectively, to the PPSA of the jurisdiction from which the case emanated, the Supreme Court's interpretation of the PPSA in each case is relevant to that of any Canadian province or territory. References to the "PPSA" therefore apply to the Canadian PPSAs collectively unless a more limited sense is indicated. To the extent that reference to a specific statutory provision is required, I refer to the PPSA(Alta), supra note 19 or other jurisdiction specified.

22 Under a chattel mortgage, conditional sale agreement, or assignment of accounts by way of security, the secured creditor held title to the collateral. The proprietary effect of a floating charge was more nuanced in that the creditor's interest in the collateral was not title but rather a "charge" on the debtor's title, which crystallized upon the debtor's default. The PPSA security interest is conceptually similar to the equitable charge except that it is fixed and arises from the moment the statutory requirements of "attachment" are satisfied. For a more complete explanation of the property interests associated with prePPSA forms of transaction, see Cuming, Walsh \& Wood, supra note 19 at 2-6.

Bank Act, SC 1991, c 46, ss 425-436.1. See especially ss 427-28.

"Bank" is defined in section 2 of the Bank Act, ibid, to include the banks listed in Schedules I and II. A Bank Act security interest can only be taken in the types of property specified in the Act. The Business Development Bank is also permitted to take Bank Act security (Business Development Bank of Canada Act, SC 1995, c 28, s 15(2)(b)). 
formerly section 178, was quoted with approval by the Supreme Court of Canada in Royal Bank of Canada v. Sparrow Electric Corp.:

\begin{abstract}
The result, then, is that a bank taking security under section 178 effectively acquires legal title to the borrower's interest in the present and after-acquired property assigned to it by the borrower. The bank's interest attaches to the assigned property when the security is given or the property is acquired by the borrower and remains attached until released by the bank, despite changes in the attributes or composition of the assigned property. The borrower retains an equitable right of redemption, of course, but the bank effectively acquires legal title to whatever rights the borrower holds in the assigned property from time to time. $^{25}$
\end{abstract}

A bank's legal title allows it to claim priority over interests arising after the bank acquires its interest. However, a seller who sells goods to the debtor under a title retention sale agreement after the Bank Act interest arises will prevail over the bank, since the bank cannot acquire title to goods that are not owned by the debtor. In effect, the conception of the security interest as title makes nemo dat the rule that determines priority, absent a statutory provision dictating a different outcome. ${ }^{26}$

The PPSA radically changed the conceptual basis of secured debt in transactions that fall outside the scope of the Bank Act. Under the PPSA, the rights of secured creditors are still determined by property, but the nature of the property interest involved is very different from that of the interests recognized under the old law. A secured creditor now has a "security interest" which is by definition an interest in personal property that secures payment of the debt. ${ }^{27}$ The extent of the property interest is co-extensive with the amount of the debt and is not equivalent to title. This is true even if the contract of lending or credit between the secured creditor and the debtor defines the property interest of the creditor as title. For example, while a secured installment sale contract may state that the seller retains title to the goods sold until the purchase price is paid in full, the PPSA will instead treat the seller's interest as a "security interest," as conceived by the Act. The nature of the PPSA security interest was explained by Justice Charron in Innovation Credit Union:

While some of the historical forms of security created equitable rather than legal interests, the effect of the PPSA's functional approach, which covers all of these antecedent security interests, is to treat them all equally as "security interests" under the PPSA.

[1997] 1 SCR 411 at para 59 [Sparrow Electric], citing Bank of Montreal v Hall, [1990] 1 SCR 121 at 134, citing William D Moull, "Security Under Sections 177 and 178 of the Bank Act" (1986) 65:1 Can Bar Rev 242 at 251 [emphasis omitted].

26

The Bank Act was amended in 2011 by the addition of a limited priority rule designed to reverse the outcome of the Supreme Court of Canada decisions in Bank of Montreal v Innovation Credit Union, 2010 SCC 47 [Innovation Credit Union] and Royal Bank of Canada v Radius Credit Union Ltd, 2010 SCC 48 [Radius Credit Union]. See note 64 for a discussion of the amendment.

27 PPSA (Alta), supra note 19, s 1(1)(tt). 
[I]t is clear that having a PPSA security interest in collateral does not give a creditor full right and title to the collateral. Rather, a PPSA security interest gives the secured creditor an interest in the property to the extent of the debtor's obligation. ${ }^{28}$

This reconceptualization accommodates the possibility of overlapping or competing security interests in the same property. Assume for example that debtor gives a security interest in a widget that is worth $\$ 15,000$ to each of two lenders, both of whom have advanced $\$ 10,000$. Both secured parties have a security interest to the extent of $\$ 10,000$ in the value of the collateral, but there is insufficient value to satisfy both debts. The manner in which that value is allocated to satisfy the two claims must be ascertained according to priority rules that determine the ranking of the claims represented by the two interests. Those rules are provided not by nemo dat but by statute. While either secured party may seize and sell the collateral in the event of default by the debtor, the priority ranking of their interests will determine (1) whether the competing interest will remain extant through a sale of the collateral; and (2) the manner in which proceeds of sale are distributed. ${ }^{29}$ The same approach applies regardless of the terms by which a loan or credit agreement defines the rights of the secured creditor: in other words, whether as a "security interest" or as title. As observed by Justice Iacobucci in Giffen (Re), reversing the British Columbia Court of Appeal's decision in a priority dispute between the holder of an unperfected security interest in a car and the trustee in bankruptcy:

The Court of Appeal in the present appeal did not look past the traditional concepts of title and ownership. But this dispute cannot be resolved through the determination of who has title to the car because the dispute is one of priority to the car and not ownership in it. ${ }^{30}$

The statutory conception of the PPSA security interest facilitates the operation of its priority rules: freed from the constraints of title, the rules may be based on other principles. Under the PPSA, the priority ranking of a security interest relative to other interests is determined by whether it is "perfected" in the manner specified by the Act, which ordinarily depends on whether it is registered in the Personal Property Registry. ${ }^{31}$ Registration in turn provides the means by which the existence of a security interest can be discovered by those who might acquire an interest in the collateral through dealings with the debtor. A registered interest will be disclosed by a properly framed search of the registry conducted using the debtor's name. ${ }^{32}$ The priority system of the PPSA is relatively complex, in that it includes a number of specific rules designed to address particular types of credit relationships and

Innovation Credit Union, supra note 26 at paras $42-43$ [citations omitted].

If the enforcing creditor's interest has priority over a subordinate interest, both interests will be eliminated by the sale and the debt secured by the senior interest will be paid out first from the proceeds, after reimbursement for the costs of enforcement. If the enforcing creditor's interest is subordinate to another interest, the senior interest will survive the sale and follow the collateral into the hands of the buyer unless its holder agrees to discharge it. See PPSA (Alta), supra note 19, s 60(12) (with respect to the title of the buyer) and ss 60(1) and 61(1) (with respect to the distribution of proceeds of realization). [1998] 1 SCR 91 at para 28.

A security interest may be perfected by other means. All methods of perfection are means by which the existence of the security interest is made apparent to a third party who might deal with the debtor, except when perfected status is conferred automatically and temporarily by the PPSA. See Cuming, Walsh \& Wood, supra note 19 , ch 5.

32 Where the inquiry relates to goods classified as "serial number goods," a registry search may also be conducted by searching the serial number of the goods. However, registration by serial number is not always required. See generally Cuming, Walsh \& Wood, ibid at 231, 349-52. 
different types of collateral. However, the residual or default priority rule illustrates the theory of priority based on the discoverability of the interest or interests in question. Priority as between two security interests perfected by registration goes to the first to register. As between a perfected and an unperfected security interest, the perfected interest has priority. ${ }^{33}$

\section{CONCEPTIONS OF PROPERTY IN JUDGMENT ENFORCEMENT LAW}

The proprietary foundations of judgment enforcement vary across the country, depending on whether the law of a given jurisdiction remains essentially the law inherited from England $^{34}$ or has been reformed by modern legislation. A handful of jurisdictions have implemented statutes comprehensively reforming judgment enforcement law in much the same way that the PPSAs comprehensively reformed secured transactions law. ${ }^{35}$ In all cases, whether under reformed or unreformed judgment enforcement systems, a judgment creditor's rights of enforcement against property of a judgment debtor and the priority of those rights relative to competing claims depends on the way in which the enforcement device employed is conceptualized.

In unreformed systems, the rights of judgment creditors are based on a collection of unrelated enforcement processes, each of which has a different scope of operation and a different proprietary foundation. For example, the writ of execution "binds" the goods of a judgment debtor on delivery to the sheriff while the garnishee summons "attaches" wages, deposit accounts, and other obligations owed to a judgment debtor on delivery to the garnishee. ${ }^{36}$ Each enforcement process has its own consequences in terms of the priority of competing claims to the affected property: there is no unitary priority system. Where judgment enforcement law has been reformed through enactment of a comprehensive statutory regime, these conceptual differences have been swept away. The processes for enforcement against various types of property may differ but all are based on a unitary conception of the proprietary basis for enforcement, which in turn facilitates the application of a single system of priority rules. The conceptualizations employed in the reformed systems implemented by the Saskatchewan Enforcement of Money Judgments Act and the Alberta Civil Enforcement Act illustrate the point. ${ }^{37}$

In Alberta, a judgment can only be enforced if a writ of enforcement is issued on the judgment and registered in the Personal Property Registry as required by the CEA. Once replicating English common law and statute law, though some English statutes remain operative as received law.

35 In chronological order of enactment, Civil Enforcement Act, SA 1994, c C-10.5 (now RSA 2000, c C-15) [CEA cited to RSA 2000]; Judgment Enforcement Act, SNL 1996, c J-1.1; The Enforcement of Money Judgments Act, SS 2010, c E-9.22 [EMJA (Sask)]; EMJA (NB), supra note 20. 
registered, the writ "binds" all exigible personal property of the judgment debtor. ${ }^{38}$ While the binding effect produced by registration does not give the judgment creditor an interest in property of the judgment debtor, the writ itself represents in rem rights of enforcement that may be realized through sale or collection of the property under processes initiated by the judgment creditor. The processes available under the Act are merely methods by which the writ may be enforced. ${ }^{39}$ The result is a unitary conception of the proprietary foundation for enforcement of judgments, which in turn allows for the application of a unitary system of rules that determine the priority of the writ as against competing claims to the debtor's property, including the claims of secured creditors.

Saskatchewan judgment enforcement law operates in a similar way but the statutory approach to rights of enforcement is somewhat more complex. ${ }^{40} \mathrm{~A}$ judgment creditor can have a judgment enforced by delivering an enforcement instruction to the sheriff. The enforcement instruction has no proprietary effect, but the sheriff is authorized by statute to seize and sell or collect the debtor's property. However, registration of a judgment in the Personal Property Registry gives rise to an enforcement charge on the property of the debtor. ${ }^{41}$ The charge does have proprietary effect and, rather like the binding writ in Alberta, represents in rem rights of enforcement against the debtor's property that have a priority status relative to other interests, including security interests. As in Alberta, priority with respect to all types of personal property is determined by a unitary set of statutory priority rules. $^{42}$

\section{The Property Rights OF CREDitors in BANKRUPtCY}

Creditors' rights are significantly affected by a debtor's bankruptcy. The property of a bankrupt debtor vests in the trustee in bankruptcy, who has the statutory power to liquidate it and distribute the proceeds of sale to unsecured creditors according to the distribution scheme prescribed by the Bankruptcy and Insolvency Act. ${ }^{43}$ The claims of unsecured creditors in bankruptcy are based on their rights against the debtor's property realized through the title acquired on their collective behalf by the trustee. The impact of bankruptcy on the claims of secured and judgment creditors is discussed below.

CEA, ibid, s 33(2). The notion of the binding effect was carried over from the English conception of the writ of execution, which bound the goods and certain other property of the judgment debtor upon delivery to the sheriff. In its report on reform of Alberta judgment enforcement law, the Alberta Law Reform Institute described the binding effect as "a cloud on the debtor's title to the bound goods, a cloud that goes with the goods if they are transferred to another." (Alberta Law Reform Institute, Enforcement of Money Judgments Volume 1 (Edmonton: Alberta Law Reform Institute, 1991) at 33.)

39 A writ may be enforced through the seizure and sale of personal property or the sale of land by a civil enforcement agency, by garnishment of obligations or by a receiver acting under the appointment of the court. In addition, the court may grant whatever order may be required to effect enforcement when the usual processes are ineffective. See generally Ronald CC Cuming \& Donald H Layh, The Saskatchewan Enforcement of Money Judgments Act: Commentary and Analysis (Regina: Queen's Printer, 2012).

EMJA (Sask), supra note $35, \mathrm{~s} 22$.

42 For a more complete explanation and comparison of the concepts of property employed in the EMJA (Sask) and the CEA, see Tamara M Buckwold, "The Reform of Judgment Enforcement Law in Canada: An Overview and Comparison of Models for Reform” (2017) 80:1 Sask L Rev 71 at 91-98. RSC 1985, c B-3 [BIA]. See BIA, s 71 for the vesting of property in the trustee. 


\section{Property as the Interface BETWEEN DEBT RECOVERY REGIMES}

With the foregoing explanation of the property-based rights of creditors in mind, we can examine the role of property as the interface between the regimes of secured transactions, reformed judgment enforcement law, and bankruptcy.

Consider first the connection between judgment enforcement law and the law of secured financing. How are the enforcement rights of judgment creditors ranked as against those of secured creditors?

Imagine that a judgment debtor's property is subject to a security interest. In Alberta, the binding effect of the writ is overlaid on the debtor's interest, which is subject to the security interest. Given that neither the security interest nor the writ represent title to the property, both can subsist simultaneously. While the writ and the security interest differ conceptually, they are functionally similar in that each represents proprietary rights inhering in the debtor's property which justify seizure or collection of that property to the extent necessary to satisfy the underlying monetary claim. ${ }^{44}$ As in the case of competing security interests in the same property, the property rights represented by the security interest and the writ, respectively, must be ranked in priority to determine: (1) whether a sale to enforce the security interest or the writ, respectively, will eliminate the property rights of the competing claimant; and (2) how the proceeds of a sale are distributed as between the holder of the security interest and the writ. Priority is determined by statutory rules provided by the $C E A,{ }^{45}$ based primarily on the time at which the competing claims were registered. Subject to prescribed exceptions, priority as between a writ and a security interest in personal property will go to the first to register in the Personal Property Registry. In effect, judgment enforcement law is integrated with personal property security law through a shared functional approach to the characterization of property interests, and a common policy-based approach to priority.

In Saskatchewan, the enforcement charge produced by registration of a judgment supports a similar approach to the ranking of security interests in personal property as against the rights of judgment creditors. Like the binding writ, the enforcement charge is functionally similar to a security interest in that it comprises the proprietary basis for enforcement of the underlying judgment debt relative to third party claims to the debtor's property. The EMJA (Sask) provides priority rules that determine whether a security interest or enforcement charge, respectively, survives an enforcement sale of the subject property and how the proceeds of sale are distributed as between the secured creditor and judgment creditor. The EMJA (Sask) goes further than does the CEA in integrating judgment enforcement law with the PPSA. Rather than providing a separate set of rules governing priorities as between an

44 I use the term "proprietary rights" rather than "property interest" in recognition of the nature of the rights underpinning judgment enforcement. Although the binding writ in Alberta and the enforcement charge in Saskatchewan create in rem rights of enforcement that attach to the debtor's property, those rights do not amount to a property interest held by the judgment creditor whose act of registration has produced them. See further Buckwold, supra note 42.

45 The priority rules ranking competing claims to personal property are located almost entirely in the CEA, but are supplemented by a PPSA priority rule dealing with the priority of a security interest as against a writ in relation to future advances made by the secured party. See CEA, supra note 35, Part 4, Division 2; PPSA (Alta), supra note 19, s 35(6). 
enforcement charge and a security interest, the EMJA (Sask) incorporates the PPSA priority system by reference. Section 23(1) provides:

Except as otherwise provided in this Act or the regulations, an enforcement charge has the same priority in relation to both prior and subsequent interests in property charged as a perfected security interest, other than a purchase money security interest, to which The Personal Property Security Act, 1993 applies. ${ }^{46}$

It is possible to rank the rights of judgment creditors as against those of secured creditors because, and only because, those rights are conceptualized in terms of property. Debts cannot have a priority ranking in the abstract. They can have priority only as embodied in proprietary rights that inhere in the property of the debtor. To put it differently, monetary claims can have priority only with respect to identified property, and that priority can only be based on rights in or to that property. It is meaningless to say that the claim of Bank A has priority over the claim of Judgment Creditor B. Bank A can only have priority over Judgment Creditor B with respect to identified property and neither can assert rights in relation to that property unless those rights have a proprietary foundation. The "black letter" priority rules of commercial law are overlaid on the property interests that are foundational to the determination of creditors' rights.

Property also creates the interface between provincial secured transactions law and the federal law of bankruptcy. Here, the interface is between the property rights embodied in a security interest and the property rights of the trustee in bankruptcy. However, here there is no integrated set of statutory rules to determine priority. Rather, priority flows from the fundamental common law rule of nemo dat.

Since the trustee acquires only what the debtor has, the trustee takes subject to existing security interests. ${ }^{47}$ A perfected security interest may be enforced post-bankruptcy through seizure and sale of the collateral because it is a property interest: the property rule of nemo dat governs and is not displaced by legislation. While an unperfected security interest is also a property interest, it is not "effective" against the trustee ${ }^{48}$ and is eliminated when the collateral is sold or distributed under the statutory rules governing the trustee's dealings with the bankruptcy estate. ${ }^{49}$ That result follows from the fact that property rights are defined by provincial law, in this case, the PPSA, which ascribes the quality of ineffectiveness to an unperfected security interest in property of a bankrupt debtor: the common law rule of nemo dat is qualified by property-defining legislation.

In much the way that an unperfected security interest exists but is effectively nullified in bankruptcy by a PPSA rule, the proprietary rights underpinning enforcement of judgments under provincial law may continue to exist but are effectively nullified by a provision of the

EMJA (Sask), supra note 35, s 23(1). Section 23(2) provides the qualifying rule that "[p]roperty that is inventory or proceeds of inventory within the meaning of The Personal Property Security Act, 1993 [SS 1993, c P-6.2 [PPSA (Sask)]]is deemed not to be inventory for the purposes of subsection (1)." This precludes application of the specialized PPSA priority rules that would otherwise apply to an enforcement charge in property categorized as inventory. Supplementary rules are provided to address specific situations.

47 See Roderick J Wood, Bankruptcy and Insolvency Law, 2nd ed (Toronto: Irwin Law, 2015) at 131 et seq.

48 PPSA (Alta), supra note 19, s 20(a)

$49 \quad$ See Giffen (Re), supra note 30. 
BIA. ${ }^{50}$ Section 70(1) provides that a bankruptcy order or assignment "takes precedence over" the rights of judgment creditors, however conceptualized..$^{51}$ Nemo dat is overridden by the federal statute, which can displace provincially defined rights of property through the doctrine of paramountcy. The trustee may therefore liquidate the bankrupt's property and distribute the proceeds without regard to the proprietary rights that could be asserted by judgment creditors prior to bankruptcy. Judgment creditors accordingly share in a bankruptcy distribution as general unsecured creditors. A judgment creditor who could have recovered the entire amount of their judgment through enforcement against property of the debtor under judgment enforcement law may therefore recover only a fraction of the judgment debt in bankruptcy, where they will be obliged to share with all those who have a provable claim, many or most of which may not have been reduced to judgment.

The fact that the BIA suspends the enforcement of proprietary rights under judgment enforcement law while recognizing perfected security interests has priority implications. Under the judgment enforcement law of Saskatchewan and Alberta, an enforcement charge or writ of enforcement may have priority over a security interest in the property of the debtor if the judgment (in Saskatchewan) or writ (in Alberta) is registered in the Personal Property Registry before the security interest is registered. If the charge or writ ceases to be effective in bankruptcy while the security interest persists, the initiation of bankruptcy proceedings allows the secured creditor to assert priority over the rights of judgment creditors embodied in the charge or writ. In effect, priorities may be reversed in favour of a creditor who holds a perfected security interest. The EMJA (Sask) contains a rule designed to forestall that result.

Section 26(1) of the EMJA (Sask) provides that " $[\mathrm{t}]$ he trustee in bankruptcy of a judgment debtor succeeds to the interest of a judgment creditor under an enforcement charge affecting the property of the judgment ... [created by registration] before the date of bankruptcy." 52 The wording of the BIA that gives bankruptcy proceedings "precedence" over the rights of creditors under judgment enforcement law accommodates the view that the enforcement charge defined by provincial law survives bankruptcy but does not take priority over the collective rights of creditors under the bankruptcy regime..$^{33}$ The EMJA (Sask) then allows the trustee to exercise the rights embodied in the charge for the benefit of the bankruptcy estate - that is, for all unsecured creditors entitled to a share rather than for judgment creditors alone. This preserves the priority of the enforcement charge as against a security interest in the debtor's property as that priority is determined by provincial law, while recognizing the collective enforcement regime of bankruptcy. ${ }^{54}$

BIA, supra note 43 , s $70(1)$

The list of processes included in BIA, ibid, does not specifically include the Alberta writ of enforcement or Saskatchewan enforcement charge, but the general reference to "judgments" and "other processes against the property of a bankrupt" clearly includes all judgment enforcement rights created by provincial law.

52 EMJA (Sask), supra note 35, s 26 (1)

53

The courts have held that proprietary rights conferred on judgment creditors by provincial law do not survive bankruptcy. However, the EMJA (Sask) provision differs from those considered in the case law and, arguably, supports a different conclusion. For further discussion of the constitutional validity of the provision, see Ronald CC Cuming, "When an Unsecured Creditor is a Secured Creditor" (2003) 66:1 Sask L Rev 255 at 267-71; Cuming \& Layh, supra note 40 at 130; Buckwold, supra note 42 at 96-97. A simple example illustrates the result:

A judgment in the amount of $\$ 10,000$ is registered in the Personal Property Registry, creating an enforcement charge that charges the judgment debtor's personal property to the extent of $\$ 10,000$. A lender lends $\$ 10,000$ to the debtor and takes a security interest in a piece of equipment owned 
The role of property as the interface between otherwise discrete legal regimes governing creditors' rights is illustrated in a different context by a companion set of Supreme Court of Canada decisions, Innovation Credit Union and Radius Credit Union. ${ }^{55}$ The cases before the Supreme Court involved priority competitions between security interests in agricultural implements taken by chartered banks under the Bank Act and security interests in the same implements taken by credit unions under the PPSA (Sask). As we have seen, the PPSA adopts a functional definition of the property interests of secured creditors and determines the priority of those interests through rules based on discoverability, primarily through registration. The Bank Act defines a security interest falling within its scope in terms of title, with priority determined by nemo dat.

In Innovation Credit Union, Justice Charron explained the nature of a Bank Act security interest and the basis on which the Act determines priority. Since the bank acquires the debtor's title to the property subject to the security agreement, the bank takes subject to preexisting interests in the debtor's title. At the time the Bank Act interest arose, the debtor's implements were subject to a PPSA security interest previously granted to the Credit Union, though not perfected. ${ }^{56}$ In order to determine what the Bank acquired under the Bank Act, it was therefore necessary to investigate the nature of a PPSA security interest.

In determining what interest the debtor may have already conveyed to another creditor and, in such circumstances, what interest he or she had left to convey to the bank at the time of execution of the Bank Act security agreement, it becomes necessary to resort to the provincial property law, either at common law or under applicable provincial statutes. It is at this point that resorting to the PPSA becomes relevant. ${ }^{57}$

Justice Charron explained the character of the PPSA interest in the terms quoted earlier. ${ }^{58}$ Since the Credit Union already had a valid property interest in the collateral at the time the Bank Act security interest was granted, the Bank could only acquire its interest subject to the Credit Union's interest: in effect, the Credit Union's PPSA security interest had priority over the Bank's Bank Act interest. The fact that the PPSA security interest was not perfected did not preclude its existence and was not relevant, since perfection was not recognized as a factor in determining priority under the Bank Act.

The issue presented in Radius Credit Union was slightly different. ${ }^{59}$ The competition was between a Bank Act security interest held by the Royal Bank of Canada and a PPSA security interest held by Radius Credit Union, each of which were granted under security agreements that predated the debtor's acquisition of the implements in dispute. The Credit Union's

by the debtor to secure the loan. The lender registers the security interest in the Personal Property Registry. Under the EMJA (Sask) priority rules, the enforcement charge has priority over the security interest because it was registered first. The debtor then becomes bankrupt, the lender declares the debtor in default and claims the equipment, which is worth $\$ 15,000$. However, the trustee can claim priority over the lender with respect to the value of the equipment to the extent of the $\$ 10,000$ secured by the enforcement charge and that amount goes into the bankruptcy estate. Innovation Credit Union, supra note 26; Radius Credit Union, supra note 26.

The bank's intention to acquire its interest was registered with the Bank of Canada before the Bank Act agreement was executed, as required by the Bank Act, supra note 23. While pre-agreement registration is a condition of the validity of a Bank Act interest, registration under the Bank Act plays no role in determining priority. See Bank Act, ibid, s 427(4).

Innovation Credit Union, supra note 26 at para 30.

Ibid.

Radius Credit Union, supra note 26. 
security agreement was executed before the Bank's. As in Innovation Credit Union, the Credit Union had not registered its interest in the Personal Property Registry so its interest in the debtor's after-acquired property was unperfected. ${ }^{60}$

Justice Charron characterized the nature of a Bank Act interest in after-acquired property on the basis of the wording of the Bank Act interpreted in light of the approach taken in equity to the recognition of interests in future property. She concluded that although the Bank Act interest did not attach until the implements were acquired by the debtor, it arose in inchoate form at the time the security agreement was made: "[T]he Bank Act effectively creates an inchoate proprietary interest in the after-acquired property from the time of delivery of the security agreement, a notion that had been recognized in equity."

Justice Charron also found that the wording of the PPSA supported the conclusion that a PPSA security interest arises in inchoate form when the security agreement is made, though it does not attach until the debtor acquires the collateral subject to the agreement. Drawing on the judgment of Justice Gonthier in the Supreme Court's decision in Sparrow Electric, Justice Charron concluded:

\footnotetext{
While the statutory interest created in after-acquired property is necessarily inchoate in nature until the debtor acquires rights in the property, that does not change the fact that, as of the date of execution, the creditorin this case the Credit Union - acquired an interest in the after-acquired property which derogated from the debtor's title. $^{62}$
}

Once it was determined that the respective property interests involved arose in inchoate form upon execution of the security agreements by which they were created, the priority dispute could be resolved on the same basis as was the dispute in Innovation Credit Union. Since the Credit Union's inchoate interest in the debtor's property arose first, the Bank acquired the debtor's title subject to that interest: nemo dat again determined priority.

The cogency of the notion that a creditor can have a property interest in property that the debtor has not yet acquired is debatable. One might question both Justice Charron's reading of the statutes and her interpretation of the principles of equity governing interests in afteracquired property. ${ }^{63}$ Nevertheless, there is no doubt that it was through conceptions of

Innovation Credit Union, supra note 26.

Radius Credit Union, supra note 26 at para 19.

Ibid at para 31 [emphasis in original].

Justice Charron confirmed the decision of the Saskatchewan Court of Appeal in the result but departed from the reasoning advanced by Justice Jackson on behalf of that Court. Like Justice Charron, Justice Jackson held that priority as between a Bank Act interest and a PPSA interest that attach simultaneously when the debtor acquires the collateral goes to the party whose security agreement was executed first. However, the reasoning advanced by Justice Jackson in support of that result was less contentious than and arguably preferable to that of Justice Charron. After a careful review of the authorities, Justice Jackson concluded that the outcome was determined by the established principle of qui prior est tempore potior est jure (whomever is first in time is first in right). Justice Charron's recognition of an "inchoate" property interest that somehow exists but does not attach until the debtor acquires the collateral produced the right result on the facts of the case but is conceptually paradoxical and adds an uncertain element to the law. A property interest once recognized takes on a life of its own and the broader implications of an inchoate interest in a different context are difficult to predict. 
property that the gap between the Bank Act and the PPSA was bridged. Property provided the means by which rights arising under discrete statutory systems could be reconciled. ${ }^{64}$

We can now see that the debt recovery regimes of commercial law are grounded in property and linked together through the rules under which the property interests supporting enforcement are defined and ranked. It is possible to fully understand the rights defined by any one of the three systems only by seeing them in relation to the rights defined by the others.

\section{Property at the Boundaries OF COMMERCIAL LAW}

Most problems in commercial law can be resolved within the systems of rules that we think of as commercial law itself. However, some commercial law problems engage interests arising under areas of law that are generally not viewed as part of commercial law doctrine. Here too, property plays a determining role. Commercial law rights and interests can be reconciled with rights or interests that fall outside the boundaries of commercial law on the basis of their respective proprietary quality. In effect, property provides the bridge between commercial law and other areas of law. The Supreme Court of Canada decision in $i$ Trade Finance Inc. v. Bank of Montreal ${ }^{65}$ illustrates this point.

i Trade Finance (i Trade) loaned money to Webworx Inc. (Webworx) on the basis of fraudulent representations regarding Webworx's business operations. The loan was unsecured. Webworx paid funds received from i Trade to the company president, Ablacksingh, as salary and corporate loans. Ablacksingh used the money to purchase shares held in an investment account in the name of himself and his wife, Ramsackal. Ablacksingh subsequently obtained a line of credit from the Bank of Montreal (BMO) on the basis of an agreement under which the shares were pledged to the bank as security for repayment. After discovering the fraud, i Trade sued Websworx and Ablacksingh. A consent order was granted directing that the shares be sold and the proceeds held in trust pending further order. At trial, Justice Belobaba, awarded i Trade damages against Webworx and Ablacksingh and "declared that Webworx and Mr. Ablacksingh held 'any real or personal property or any other assets that they purchased with funds provided by [i Trade] to Webworx as constructive trustee for the benefit [of] i Trade." ${ }^{, 66} \mathrm{He}$ also granted i Trade a tracing order and "[u]pon execution of the tracing order, $i$ Trade could elect in whole or in part between (1) imposing a constructive trust and/or an equitable lien; and (2) seeking a personal remedy against any

The Bank Act, supra note 23 was subsequently amended to reverse the outcome in these cases in favour of a bank that finds itself in the position of those involved in the litigation. The problem from the banks' point of view was that, in both cases, they were subordinated to unknown security interests that were unperfected and therefore could not be discovered through a registry search. Section 428(1) of the Bank Act now provides that a Bank Act interest has priority over the claim of "any person who has a security interest in [the collateral] that was unperfected at the time the bank acquired its security in the property." The amendment may be regarded as unfortunate both as a matter of policy and because it further complicates the interface between the Bank Act and the PPSA. For a review of the several problems raised by the amendment, see Roderick J Wood, "Bank Act - PPSA Interaction: Still Waiting for Solutions" (2012) 52:2 Can Bus LJ 248; Clayton Darryl Bangsund, “A Critical Examination of Recently Proposed Amendments to the Bank Act Security Provisions" (2012) 75:2 Sask L Rev 211. 2011 SCC 26 [i Trade].

Ibid at para 7, citing the unreported decision of Justice Belobaba (5 September 2006) at para 5. 
party liable. ${ }^{\prime 67} \mathrm{i}$ Trade then sought a declaration that it was entitled to the funds derived from sale of the shares in Ablacksingh's investment account, which were also claimed by BMO on the basis of its security interest in the account. The Ontario Court of Appeal reversed the trial decision in favour of $\mathrm{i}$ Trade and allocated the funds to BMO. The Supreme Court affirmed the Ontario Court of Appeal decision.

Although the dispute addressed in the case was commercial in nature, i Trade's rights were not determined by commercial law per se. $\mathrm{i}$ Trade did not hold a security interest in the shares, nor did it have rights in relation to the shares as a judgment creditor. However, resolution of the dispute depended on the property rights of the competing claimants. Justice Deschamps prefaced her analysis with this:

To resolve this question, the Court must determine the nature of the interests held by these two parties and clarify the role that Ontario's Personal Property Security Act, R.S.O. 1990, c. P.10 ("PPSA"), plays in this determination. ${ }^{68}$

Justice Deschamps first addressed the characterization of BMO's rights in the investment account. This required consideration of the substantive content of the concept of "security interest" defined by the PPSA and the corollary PPSA rule under which a security interest is enforceable against third parties only if it has "attached" as required by the Act. ${ }^{69}$ The interest claimed by BMO was clearly a security interest, since it was an interest taken in the investment account to secure repayment of the funds advanced by BMO to Ablacksingh under the line of credit. The question then was whether the security interest had attached to the property represented by the account. Justice Deschamps concluded that it had, since the contract under which Webworx acquired the funds had not been voided at the time that BMO acquired its interest: Ablacksingh and Ramsackal had "rights" in the investment account supporting attachment of BMO's interest. ${ }^{70}$ The question of whether the proceeds of the investment account went to BMO or i Trade then depended on the priority of their respective property interests in the account: BMO's PPSA security interest as against i Trade's interest as beneficiary under the constructive trust declared by Justice Belobaba.

Justice Deschamps expressly recognized that the PPSA provides no rule to resolve a priority competition between a PPSA security interest and the equitable interest of a trust beneficiary. Such a dispute simply falls outside the scope of the PPSA. However, the

Ibid.

Ibid at para 1.

Personal Property Security Act, RSO 1990, c P.10, ss 1(1) “security interest," 11(1) [PPSA (Ont)].

The analysis on this point seems to assume that when the BMO security interest attached the debtors' interest in the account was bare legal title, subject to i Trade's equitable interest arising under the judgment of Justice Belobaba. This in turn assumes that the declaration of constructive trust had retroactive effect, since it was not granted until after BMO entered into its security agreement with Ablacksingh and Ramsackal. The decision is therefore authority for the conclusion that bare legal title comprises "rights" sufficient to support attachment of a PPSA security interest in property subject to a trust. 
character of the PPSA security interest as a property interest provided the basis for resolution of the dispute through application of a general rule of property:

It is true that the internal priority rules of the PPSA cannot be invoked to resolve the dispute. However, it does not follow that the provincial security interest created under the PPSA does not exist outside these priority rules. $^{71}$

The external rule that applied was the bona fide purchaser for value rule. The Supreme Court quoted the explanation offered by Lionel Smith:

The full name of the equitable defence is 'bona fide purchase of a legal interest for value without notice of a pre-existing equitable interest'. The effect of the defence is to allow the defendant to hold its legal proprietary rights unencumbered by the pre-existing equitable proprietary rights. In other terms, where the defence operates, the pre-existing equitable proprietary rights are stripped away and lost in the transaction by which the defendant acquires its legal proprietary rights. ${ }^{72}$

BMO's interest fell within the ambit of the rule because it "is a security interest that was created by statute and is recognized at law." "73 Implicitly, the Supreme Court held that a statutory property interest is equivalent to a legal interest at common law for purposes of the rule. Since BMO acquired its interest for value and did not have notice of i Trade's equitable interest in the account, BMO's interest prevailed.

Once more, property was the medium through which competing claims were resolved. It was characterization of the parties' competing rights in terms of property that allowed them to be ranked under a recognized rule of law.

\section{The Creative Power of Commercial Law: Property as THE CONCEPTUAL SOlUtion to Practical Problems}

\section{A. Property is Created by LaW}

I turn now to the second theme in my argument that property is the doctrinal foundation of commercial law; namely, that commercial law is both built around conceptions of property and defines the conceptions of property around which it is built. In short, commercial law invents new property interests to meet real world needs. Property interests may be and are defined by commercial law specifically to achieve functional goals. The result is function embodied in an idea about property. This is the invisible magic of commercial law.

The courts have been performing this kind of magic for a very long time. The legal conceptualization of a debt provides an obvious example. In the mists of history, a debt was only a personal obligation. But the law came to recognize that the personal obligation to satisfy a debt has value, just as the gold under the mattress has value, and so that obligation

i Trade, supra note 65 at para 59, citing Innovation Credit Union, supra note 26 at para 30.

$i$ Trade, ibid at para 60, citing Lionel D Smith, The Law of Tracing (Oxford: Clarendon Press, 1997) at 386 [footnotes omitted].

$i$ Trade, ibid at para 61 . 
became not just a personal obligation as between debtor and creditor but also an intangible "thing" that is property of the account creditor — a species of chose in action. The recognition that a debt was a species of property that could be the subject of transfer significantly expanded the ambit of commercial law and the results it could achieve. ${ }^{74}$ Property may be conceptualized in terms that meet a commercial need or provide the basis for resolution of a commercial law problem. ${ }^{75}$ Two Supreme Court of Canada decisions illustrate the point.

\section{B. The Definition of Property}

In Saulnier v. Royal Bank of Canada ${ }^{76}$ the question before the Supreme Court was whether "personal property" for purposes of the BIA and the Nova Scotia PPSA, ${ }^{77}$ respectively, includes a licence to fish. More specifically, can a licence to fish be the subject of a PPSA security interest? The Supreme Court said yes, notwithstanding that a licence is not property at common law.

The Nova Scotia PPSA, like its counterparts in most other jurisdictions, offers no direct guidance on the question. The PPSA defines "personal property" simply by listing the categories of property addressed by its provisions, being "goods, chattel paper, investment property, a document of title, an instrument, money or an intangible." 78 Each category is in turn defined. "Intangible" is a residual category capturing "personal property other than" property falling within the other listed categories. In the result, personal property includes an intangible, which includes personal property other than the listed kinds. An intangible therefore must be "personal property." Hence the question: while a licence to fish is clearly intangible, is it personal property?

Justice Binnie described the practical implications of the proprietary characterization of a fishing licence:

A commercial fisher with a ramshackle boat and a licence to fish is much better off financially than a fisher with a great boat tied up at the wharf with no licence. Financial institutions looking for readily marketable loan collateral want to snap up licences issued under the federal [fishery] Regulations, which in the case of the lobster fishery can have a dockside value that fluctuates up to a half a million dollars or more. Fishers want to offer as much collateral as they can to obtain the loans needed to acquire the equipment to enable them to put to sea. ${ }^{79}$

See e.g. Worthington, "Property as Proxy," supra note 16 at 336 [footnotes omitted]: "The liberalisation of laws of assignment, in equity, not at common law, is a familiar story. But it is nonetheless a significant commercial advance. It made these assets usable wealth, able to be traded, and, later, used as security for engagements." Equity permitted the assignment of personal obligations that were unassignable at common law. Debts, shares, and other contractual claims thus became usable wealth. For further analysis of the manner in which conceptions of property are used to meet commercial needs, see Sarah Worthington, "The Disappearing Divide Between Property and Obligation: The Impact of Aligning Legal Analysis and Commercial Expectation" (2007) 42:3 Tex Int LJ 917, first published in Simone Degeling \& James Edelman, eds, Equity in Commercial Law (Sydney: Lawbook Co, 2005) [cited to Tex Int LJ]. Among other principles of property law, Worthington considers the effectiveness and desirability of the numerus clausus principle as a limitation on the recognition of property interests (at 925-26). See also Worthington, "Property as Proxy," ibid. 2008 SCC 58 [Saulnier].

Personal Property Security Act, SNS 1995-96, c 13.

See e.g. PPSA (Alta), supra note 19, s 1(1)(gg).

Saulnier, supra note 76 at para 13 . 
While the fishing licences held by the bankrupt comprised rights with substantial market value, that in itself did not make them property. ${ }^{80}$ However, the Supreme Court recognized that what counts as "property" under a statute depends on the way in which the concept is used:

The notion of "property" is, in any event, a term of some elasticity that takes its meaning from the context. The task is to interpret the definitions in the BIA and PPSA in a purposeful way having regard to "their entire context, in their grammatical and ordinary sense harmoniously with the scheme of the Act, the object of the Act, and the intention of Parliament." 81

The Supreme Court confirmed that the concept of property under the PPSA or the BIA may differ from the concept of property at common law: "For particular purposes Parliament can and does create its own lexicon. ${ }^{.82}$ In essence, property is what the law says it is.

Justice Binnie considered three approaches to the characterization of rights as property, but the decision ultimately did not rest on any of the three. Drawing an analogy with the proprietary quality of a profit à prendre as recognized at common law, Justice Binnie concluded that a fishing licence is property under the BIA and the PPSA because it represents, in substance, "a licence to participate in the fishery coupled with a proprietary interest in the fish caught according to its terms and subject to the Minister's regulation." ${ }^{83}$ While Justice Binnie described this as the "preferred approach," it is not entirely clear what the approach represents, other than one that draws by analogy from established understandings of property. Stated in general terms, the case suggests that intangible rights are property if they represent a legal right to engage in a regulated activity through which the rights-holder may acquire something that is property at common law.

The decision in Saulnier may be criticized for the Supreme Court's failure to clearly define the principles to be applied in determining whether a license, or any other intangible rights, are property. Anthony Duggan identifies the unresolved tension between a formal approach, manifested in the Supreme Court's reliance on generally recognized attributes of property, and a functional approach, manifested in the passages quoted above. ${ }^{84}$ Under a purely functional approach, characterization of rights need not be based on analogy with a recognized property interest (the profit à prendre), but would be based on the value of the rights in question as a transferrable asset facilitating access to credit. Nevertheless, while the functionalist approach may have been muddled, it appears to have dominated. Property was conceived by the Supreme Court in terms that respond to the objectives of the legislation under review.

Duggan's critique rightly draws attention to the need for articulated principles according to which questions of property are determined in commercial law. However, judicial uncertainty on that front does not detract from the central point of this analysis: that

Ibid at para 15 .

Ibid at para 16, citing Ruth Sullivan, Sullivan and Driedger on the Construction of Statutes, 4th ed (Markham: Butterworths Canada, 2002) at 1.

Ibid.

Ibid at para 46.

Anthony Duggan, "In the Wake of the Bingo Queen: Are License Property?" (2009) 47:2 Can Bus LJ 225. 
commercial law defines property in terms that are unique to commercial law and respond to the commercial needs of its subjects. What counts as property within commercial law may not be, and need not be, the same as what counts in other contexts.

The legislatures in some jurisdictions have resolved the problem of licences and similar rights by expressly defining property for purposes falling within the scope of the PPSA in terms that meet its functional objectives. Under the Saskatchewan PPSA, "intangible" is defined to include a "licence," 85 which is defined in terms that go beyond the scope of the Supreme Court decision in Saulnier:

\footnotetext{
"licence" means a right, whether or not exclusive, that is transferrable by the licensee, with or without restriction or the consent of the licensor:

(i) to manufacture, produce, sell, transport or otherwise deal with personal property;

(ii) to provide services; or

(iii) to acquire personal property;
}

and includes a licence that is subject to cancellation and reissuance by the licensor to another party at the request of either the licensee or the secured party: ${ }^{86}$

Similar provisions are incorporated in the British Columbia $P P S A^{87}$ and will likely be adopted in other jurisdictions in future. ${ }^{88}$

Judgment enforcement legislation in Alberta goes even further. The CEA defines property to include "any right or interest that can be transferred for value from one person to another," a legislated departure from the Supreme Court's view that rights do not qualify as property simply because they have commercial value. ${ }^{89}$

The expansive manner in which property is framed in commercial law is not a matter of legal imperialism but rather a response to recognized needs. ${ }^{90}$ In the case of the PPSA, the recognition of valuable rights as property serves to augment a debtor's collateral base and thereby enhance the debtor's access to credit. In the case of the CEA, this approach enlarges the pool of assets against which judgments may be enforced through seizure and sale, thereby advancing the likelihood that judgment debts will be satisfied.

The functional approach to property in commercial law should not be confused with one that determines outcomes through facilitative rules. There is a difference between saying that

85 PPSA (Sask), supra note 46, s 2(1)(w).

$86 \quad$ Ibid, s 2(1)(z) as amended by The Personal Property Security Amendment Act, 2019, SS 2019, c 15, s $3(1)(\mathrm{c})$.

$87 \quad$ Personal Property Security Act, RSBC 1996, c 359, s 1(1) [PPSA (BC)].

88 This approach was recommended to other jurisdictions by the Canadian Conference on Personal Property Security Law, "Proposals for Change to the Personal Property Security Acts," 2017 CanLIIDocs 3526 at Part II(5).

89 CEA, supra note 35, s 1(1)(11)(iii). For a case considering the scope of the CEA definition of "property" as it applies to a licence, see Stout \& Co LLP v Chez Outdoors Ltd, 2009 ABQB 444.

$90 \quad$ For an example of a type of property recently created by statute, see the Protecting What Matters Most Act (Budget Measures), RSO 2019, c 7, Sched 49, amending the PPSA (Ont) to recognize electronic chattel paper as a species of personal property that can be the subject of a security interest. 
a creditor can sell a license held by their debtor to satisfy a debt, and saying that a licence is property and can therefore be the subject of a security interest, which allows the secured party to resort to the property to satisfy a debt. The first is a definition of rights by means of an ad hoc rule that has no necessary connection with any other rule or set of rights. The second is a definition of rights by means of a concept, which places those rights within a structure of doctrine that recognizes other rights. A functional approach to property is not anticonceptual: rather, it represents a particular way of defining the concept of property for the purposes of resolving the issues addressed by commercial law. ${ }^{91}$

\section{The DEFINITION OF SECURITY INTEREST}

The reconceptualization of property interests through the "substance" test of the PPSA was also adopted as a device to meet a practical need; namely, the need to rationalize the law of secured lending and credit by implementing a system of rules that treats functionally similar transactions in a conceptually and functionally similar way. The system built on the platform of the legislatively defined security interest enhances fairness, efficiency, and predictability in secured transactions, facilitating accurate risk assessment, and promoting the availability of low-cost capital and credit. Any property interest that "in substance" secures payment of a debt is a security interest. The problem of ranking the claims of diverse creditors to the same property was solved by homogenization of their interests through the definition of security interest, followed by the application of priority rules based on discoverability.

The drafters of the PPSA recognized that this conceptual approach could be used to address other transactions raising similar issues: that is, to situations in which a person's apparent control over property might deceive others to their detriment. Rights of ownership in transactions that are not designed to secure an obligation, if redefined as a security interest, could be brought within the discovery-based priority system of the PPSA: thus the "deemed" security interests were born. The functional analogy between secured transactions and other transactions brought within the scope of the PPSA by means of this device may be illustrated through a simple scenario.

Assume that Person A holds a security interest in a car owned by Person B. Person $\mathrm{C}$ is considering advancing a loan to B secured by a security interest in the car. Person $\mathrm{C}$ can determine through a search of the registry whether the car is subject to a security interest that may have priority over $\mathrm{C}$ should they proceed with the contemplated loan. $\mathrm{C}$ is not at risk of being misled by the fact that B's rights in the car are subject to the invisible security interest of another person. as follows: "The functional argument is unexceptionable, but the formal argument is open to criticism because it discriminates arbitrarily between different kinds of license and it overlooks the policy considerations the court identified in the functional aspect of its judgment." Worthington, "Property as Proxy," supra note 16, rightly points out that there is risk in the judicial definition of commercial rights through conceptions of property in that policy-based decisions may be clothed in the deceptively neutral guise of property. The decision in Saulnier may be explained as an instance of the court's reluctance to articulate a clear policy rationale (e.g. access to credit) for its ambiguous approach to the definition of property. 
Now assume that $\mathrm{A}$ is not a secured creditor but rather the owner of a car that has been leased to $\mathrm{B}$. Person $\mathrm{C}$ is considering advancing a loan to $\mathrm{B}$ secured by a security interest in the car. B fails to inform $\mathrm{C}$ that they do not own the car. $\mathrm{C}$ may be induced by B's ostensible ownership to advance a loan on the security of the car, only to find that the security interest purportedly granted by B is illusory. The rule of nemo dat, if allowed to operate without qualification, means that A's rights as owner will have priority over any interest that may be acquired by $\mathrm{C}$.

The PPSA resolves the problem presented by the lease by redefining the character of the property interest held by a commercial lessor of goods under a "lease for a term of more than one year." ${ }^{92}$ The lessor's title is defined as a security interest, in the same way that a secured creditor's contractually ascribed title to property taken as collateral is defined as a security interest: here, the lessor is "deemed" to have a security interest in the leased goods. ${ }^{93}$ The lessor's interest is by that means made subject to the PPSA regime, under which the priority of a security interest is determined not by nemo dat but by publication of the interest through registration. In our scenario, A must "perfect" their security interest by registration in order to assert their rights as against third parties dealing with B. C can accordingly guard against losing the car to an unknown owner by searching the registry.

The PPSA similarly extends the concept of "security interest" to the interest of a person who acquires an account or chattel paper through an outright transfer and to the interest of a consignor under a commercial consignment. ${ }^{94}$ The result is to bring those "deemed" security interests within the scope of the PPSA priority regime for the same reasons that the interest of a commercial lessor of goods is "deemed" to be a security interest. ${ }^{95}$

The conceptualization of the owner's interest in accounts, chattel paper, and leased and consigned goods as a security interest means that the opposite party in the transaction is implicitly deemed to be the owner for purposes of the operation of the statutory priority rules. The lessee or consignee of goods under a lease or consignment that falls within the scope of the PPSA is treated as the owner of the goods and is thus able to give an interest to a third party with whom they might have dealings. The same is true of a person who transfers an account or chattel paper under an outright assignment. ${ }^{96}$

For example, lessee B in our scenario has rights that support the security interest granted to $\mathrm{C}$. If lessor $\mathrm{A}$ has not protected their deemed security interest by registration, $\mathrm{C}$ will have priority over A's interest and can claim the full value of the car under realization proceedings undertaken on B's default under the loan agreement. B, rather than A, is effectively given

92 PPSA (Alta), supra note 19, s 1(1)(z) "lease for a term of more than one year."

$93 \quad$ Ibid, ss 1(1)(tt) "security interest," $1(1)(\mathrm{z}), 3(2)$.

94 Only a consignment meeting the definition of "commercial consignment" falls within the scope of the PPSA (Alta). See ibid, s 1(1)(h).

95 Regarding the rationale for including these "deemed" security interests in The Personal Property Security Act, SS 1979-80, c P-6.1, proclaimed in 1981, see Ronald CC Cuming, "Second Generation Personal Property Security Legislation in Canada" (1981) 46:1 Sask L Rev 5 at 19-21. The other provinces have adopted the same approach, except that a true consignment does not create a "deemed" security interest in Ontario.

96 The lessee, consignee, or assignor has "rights" in the subject property that support attachment of a security interest granted to a third party as required by the PPSA. See PPSA (Alta), supra note 19, s 12(2); see also Cuming, Walsh \& Wood, supra note 19 at 257-59. 
rights of ownership in relation to C. Similarly, the consignee of goods under a commercial consignment and the assignor of an account or chattel paper is treated as owner in that they have rights supporting the conferral of an interest in the subject property on a third party. ${ }^{97}$

To reiterate, the PPSA uses conceptions of property as the basis for the resolution of a practical problem, being the potential that third parties may be misled by the appearance of ownership created by possession or control of property on the part of a non-owner. ${ }^{98}$

The PPSA's redefinition of property rights was initially difficult for lawyers and judges schooled in title-based thinking to accept. However, it was explained and endorsed by the Supreme Court of Canada in Giffen (Re). ${ }^{99}$ The owner of a car had leased it under a lease that met the PPSA definition of "lease for a term of more than one year."100 The owner-cumsecured party had not perfected its "deemed" security interest by registration. When the lessee became bankrupt, the trustee claimed the car as part of the bankrupt's estate on the basis of the PPSA priority rule under which an unperfected security interest is not effective against a trustee in bankruptcy. ${ }^{101}$ The British Columbia Court of Appeal held that the lessor was entitled to recover the car because it was not property of the bankrupt but property of the lessor, so could not vest in the trustee under the BIA: nemo dat governed the outcome. The Supreme Court of Canada found that the result was dictated by the conceptualization of property effected by the PPSA and reversed the decision. Justice Iacobucci wrote this:

In the opinion of the Court of Appeal, the bankrupt, as lessee, did not have a proprietary interest in the car, and since the trustee obtains its entitlements to the contents of the bankrupt's estate through the bankrupt, the trustee cannot assert a proprietary interest in the car. In my view, the Court of Appeal, with respect, erred fundamentally in focussing on the locus of title and in holding that the lessor's common law ownership interest prevailed despite the clear meaning of s. 20(b)(i).

The Court of Appeal did not recognize that the provincial legislature, in enacting the PPSA, has set aside the traditional concepts of title and ownership to a certain extent. T.M. Buckwold and R.C.C. Cuming, in their article "The Personal Property Security Act and the Bankruptcy and Insolvency Act: Two Solitudes or Complementary Systems?” (1997), 12 Banking \& Finance L. Rev. 467, at pp. 469-70, underline the fact that provincial legislatures, in enacting personal property security regimes, have redefined traditional concepts of rights in property:

Simply put, the property rights of persons subject to provincial legislation are what the legislature determines them to be. While a statutory definition of rights may incorporate common law concepts in whole or in part, it is open to the legislature to redefine or revise those concepts as may be

This approach to the debtor's interest is not restricted to transactions involving a "deemed" security interest. It also applies, implicitly, to a transaction under which a creditor's interest is defined contractually as title but is characterized "in substance" as a security interest under the PPSA. See Cuming, Walsh \& Wood, ibid at 256.

A lessee or consignee of goods may mislead others through their possession of the goods. An account creditor cannot be "in possession" of an account that is transferred to another person but a third party dealing with the account creditor may be misled into believing that they still own the account by the records kept by the account creditor.

$99 \quad$ Giffen (Re), supra note 30.

100 PPSA (BC), supra note 87, s 1(1) "lease for a term of more than one year."

101 Ibid, s 20(b). The car was not leased directly to the bankrupt but was leased by the owner to the bankrupt's employer, who in turn leased it to her. However, this did not affect the Supreme Court's analysis of the PPSA characterization of property rights or the application of the PPSA priority rules. 
required to meet the objectives of its legislation. This was done in the provincial PPSAs, which implement a new conceptual approach to the definition and assertion of rights in and to personal property falling within their scope. The priority and realization provisions of the Acts revolve around the central statutory concept of "security interest." The rights of parties to a transaction that creates a security interest are explicitly not dependent upon either the form of the transaction or upon traditional questions of title. Rather, they are defined by the Act itself. ${ }^{102}$

The PPSA is not the only sector of commercial law in which property rights have been redefined to meet a practical need. As we have seen, reformed systems of judgment enforcement law adopt a similar approach. The law in Saskatchewan and Alberta was rationalized through reconceptualization of the property rights underpinning enforcement of judgments. The collection of unrelated enforcement processes available to creditors under unreformed law makes for an inefficient system under which the enforcement of judgments is rendered complex and correspondingly inefficient, expensive, and uncertain. The differing conceptual foundations of the various pre-reform enforcement devices made it difficult to determine the priority of a judgment creditor's rights of enforcement relative to the rights of secured creditors and others. The conceptual unification of judgment enforcement processes under reformed systems allows for the application of a unitary system of priority rules, which in turn is designed to interface with the priority rules of the PPSA.

To conclude, property not only provides the foundation and framework of commercial law, but is the tool used by commercial law to achieve desired outcomes. The drafters of the PPSA did not simply compose a rule requiring the lessors of goods (and the holders of other "deemed" security interests) to register in order to assert their rights of ownership. They rooted a functionally driven approach in a conception of property that allows rights to be placed in a broader legal context. Further, the deemed security interest of the lessor or consignor of goods and the assignee of an account or chattel paper is not limited to the PPSA

Giffen Re, supra note 30 at paras 25-26 [emphasis added].The legislative reference is to the Personal Property Security Act, SBC 1989, c 36. In Sprung Instant Structures Ltd v Caswan Environmental Services Inc, 1997 ABCA 411, briefly reconsidered in Royal Bank of Canada v Sprung Instant Structures Ltd, 2000 ABCA 202 [collectively, the Sprung CA decisions], the Alberta Court of Appeal seems to have bypassed the PPSA's reconceptualization of the property rights associated with a lease for a term of more than one year. The Court held that a bank lender did not acquire a security interest in a leased portable structure under its general security agreement with the lessee, on the grounds that the security agreement was not intended to cover the structure. However, the Court's approach to interpretation was apparently rooted in a title-based view of the lessor's rights in the leased goods. The decision was trenchantly criticized by the New Zealand High Court in Graham v Portacom New Zealand Ltd, [2004] 2 NZHC 528, paras 24-27, a case in which application of the corresponding provisions of the New Zealand Personal Property Securities Act, (NZ) 1999/126 to very similar facts yielded the opposite result. In the subsequent Alberta Court of Queen's Bench decision in 1777575 Alberta Ltd v Sprung Instant Structures Ltd, 2014 ABQB 354 [Sprung QB], Justice Veit considered a priority dispute over a leased portable structure on facts that were almost identical to those before the Court of Appeal in the Sprung CA decisions (ibid) and, remarkably, again involved Sprung Instant Structures as the lessor. Justice Veit suggested that the Court of Appeal decisions may have been influenced by counsel's failure to properly educate the court on the PPSA approach to property (Sprung QB, ibid at paras 13, 17). After explaining the PPSA's conceptual structure, she observed that:

Giffen (Re) emphasized the revolutionary nature of personal property security legislation in

Canada. Sprung has acted throughout these proceedings as if that revolution had not taken place;

Sprung has ignored, at its peril, the fundamental changes effected by the statute in relation to ownership interests in personal property (Sprung QB, ibid at para 15).

Since Sprung Instant Structures Ltd had failed to perfect its "deemed" security interest in the leased structure, its claim was subordinate to the security interest granted by the lessee to Canadian Imperial Bank of Commerce and property perfected. 
but, once so defined, is recognized as such under reformed systems of judgment enforcement law and in bankruptcy.

\section{Conclusion}

Other academics have written about the important role of property in particular areas of commercial law. ${ }^{103}$ Often, the object of the analysis is to demonstrate and critique the consequences that follow from defining claims in terms of a property interest. ${ }^{104}$ I have written here about the role of property in a discrete branch of commercial law: that governing recovery of debt. However, I approach the subject more broadly in order to demonstrate the importance of property as the concept that not only gives depth and interest to commercial law but holds it together and provides a bridge to other areas of doctrine. I hope to have illuminated an understanding of commercial law that helps us to think through commercial law problems more clearly.

I hope also to have highlighted the need to frame commercial law legislation and judicial decisions in terms that recognize and respect the dictates of property. Rules and outcomes must fit within the framework of property interests as they are defined by and within commercial law if it is to provide a coherent basis for the predictable resolution of disputes. ${ }^{105}$ This is not to say that there is no room for debate over whether commercial law, whether created by statute or the courts, defines property correctly. The Supreme Court of Canada's invention of the "inchoate" security interest in after-acquired property may have been ill-advised. ${ }^{106}$ The view that a commercial consignor of goods is "deemed" merely to have a security interest in the goods is not incontrovertible. ${ }^{107}$ Nevertheless, the use of property in both cases fits the rights represented by the property interest so defined within a larger doctrinal structure, invoking a stable system of rules to resolve conflicting claims.

See especially Khimji, "Legal Concepts," supra note 1, discussing the conceptual structure of the STA (Ont), supra note 6. The provincial Securities Transfer Acts represent another instance of the capacity of law to define property in terms designed to perform a market function. Through it, legislators invented the "security entitlement" as a new form of property representing "the rights and property interest of an entitlement holder with respect to a financial asset that are specified in Part 6." See e.g. Securities Transfer Act, SA 2006, c S-4.5, s 1(1)(jj) [STA (Alta)]. Part 6 of the STA (Alta) then defines the rights that comprise the property interest. For an overview and explanation of the new system introduced by the Securities Transfer Acts, see Eric T Spink, "The Securities Transfer Act — Fitting New Concepts in Canadian Law" (2007) 45:2 Can Bus LJ 167; Mohamed F Khimji, "The Securities Transfer Act - The Radical Reconceptualization of Property Rights in Investment Securities" (2007) 45:1 Alta L Rev 137.

See e.g. Goode, "Ownership and Obligation," supra note 11. The article does not present a theory of the respective roles of property and obligation in commercial law but, as previously noted, focuses on two specific topics, being the manner in which property affects creditors' rights in insolvency and the implications of property in determining the rights of a buyer against a carrier with respect to negligent damage to shipped cargo.

The provisions of the CEA relating to the registration of a pre-judgment attachment order may be viewed as an instance of failure to observe this precept. Although an attachment order is essentially an order that has in personam effect as against the person to whom it is directed, the priority ascribed to registration of an attachment order has in rem consequences. The conceptual and practical problems associated with this approach are discussed in CRB Dunlop \& Tamara M Buckwold, Debt Recovery in Alberta (Toronto: Carswell, 2012) at 231-41. The judicial practice of writ saving, also described, is similarly problematic. See Radius Credit Union, supra note 26.

107 The PPSA (Ont) does not define a commercial consignment as a security interest, though all the others do. See PPSA (Ont), supra note 69, s 1(1) "security interest." 
To return to the point made at the outset, commercial law is not merely a collection of rules to be mechanically applied. Although problems in commercial law often do require the application of complex rules, the operation of the rules and the relationship between them makes sense when one sees the conceptions of property in which they are grounded. 